\title{
PENGETAHUAN DAN SIKAP MAHASISWA TENTANG PENYAKIT HEPATITIS A DI POLITEKNIK NEGERI JEMBER
}

\author{
Oleh : \\ Faiqatul Hikmah *)
}

\begin{abstract}
ABSTRAK
Terdapat kenaikan 150 persen angka penderita Hepatitis A pada bulan Februari 2012, berdasarkan data Dinas Kesehatan kabupaten Jember. Pada maret 2012 berdasarkan data Dinas Kesehatan jember, terdapat penderita hepatitis A sebanyak 120 orang yang harus dirawat di sejumlah rumah sakit dijember, diantaranya terdapat 96 orang adalah mahasiswa. Banyaknya mahasiswa yang terserang penyakit karena kawasan kampus di Jember merupakan daerah endemis virus hepatitis A.

Tujuan penelitian untuk menganalisi perbedaan pengetahuan dan sikap antara mahasiswa kesehatan dan mahasiwa non kesehatan di Politeknik Negeri Jember.

Jenis penelitian adalah penelitian survei analitik dengan pendekatan cross sectional. Penelitian dilaksanakan di kampus Politeknik Negeri Jember. Populasi berjumlah 3180 orang dan Jumlah sampel sejumlah 50 orang dengan 25 orang mahasiswa kesetan dan 25 mahasiswa non kesehatan.

Hasil penelitian dianalisi dengan menggunakan uji $T$ test independent dan TwoSample Kolmogorov-Smirnov Test, dari hasil tes tersebut diketahuai bahwa tidak ada perbedaan pengetauan dan sikap anatara mahasiswa kesehatan dan mahasiwa non kesehatan di Politeknik Negeri Jember.

Perlunya dilakukan peningkatan pengetahuan tentang hepatitis A dengan memanfaatkan media yang ada di politeknik negeri jember sebagai upaya pencegahan.
\end{abstract}

Kata Kunci : Pengetahuan, Sikap, Hepatitis A

\section{PENDAHULUAN}

Hepatitis merupakan peradangan pada liver atau hati, yang disebabkan oleh berbagai jenis obat maupun agen-agen toksik, termasuk virus. Virus yang dapat menyebabkan penyakit hepatitis antara lain : Virus Hepatitis A, virus hepatitis B, virus Hepatitis C, virus Hepatitis D, virus hepatitis E dan virus Hepatitis G (Afiati, AI. 2011).

Pada negara berkembang dimana kondisi sosial, ekonomi, hygiene, dan sanitasi lingkungan yang masih buruk sebagian besar anak-anak sudah terinfeksi virus ini sejak bayi. Keadaan ini dapat diketahui dengan adanya antibody anti virus Hepatitis A (VHA) pada pemeriksaan darah mereka. Sementara di negara industri dan negara maju lainnya, penyakit hepatitis A terutama menyerang orang dewasa muda yang sering berpergian ke daerah dengan insiden infeksi hepatitis yang tinggi (Dhafinah, 2012).

Penyakit hepatis A dahulunya dinamakan hepatitis infeksiosa. Sampai sekarang hepatitis A masih bersifat endemis di negara berkembang sehubungan dengan lingkungan dan sanitasi yang masih buruk. Pada daerah beriklim tropis seperti Indonesia, penyakit banyak timbul selama musim hujan dan terutama menyerang anak-anak dan orang dewasa muda(Dhafinah, 2012).

Merupakan infeksi sistemik akut oleh virus Hepatitis A (VHA) pada hati. Hepatitis A mempunyai masa inkubasi yang pendek (sekitar 30 hari), sangat menular, bersifat sporadis/epidemis. Penularan melalui fecal - oral (makanan minuman ) yang tercemar virus, biasanya terjadi pada daerah yang mempunyai sanitasi yang buruk (Afiati, AI. 2011).

Di Indonesia hepatitis A masih merupakan masalah. Menurut hasil penelitian Prof. Ali Sulaiman pada tahun 1993 dari seluruh penderita hepatitis akut yang dirawat di rumah sakit, hepatitis A merupakan penyebab terbanyak yaitu sebesar 39,8-25,9\% (Dhafinah, 2012).

Menurut Dinas Kesehatan Jember terdapat kenaikan 150 persen angka penderita Hepatitis A pada bulan Februari 2012. Pada bulan Januari tercatat ada 20 penderita hepatitis yang dirawat di sejumlah rumah sakit di Jember. Namun pada bulan Februari terjadi lonjakan hingga mencapai 
50 kasus atau naik 30 kasus (150 persen). Hingga awal maret 2012 berdasarkan data Dinas Kesehatan jember, sedikitnya terdapat penderita hepatitis A sebanyak 120 orang yang harus dirawat di sejumlah rumah sakit dijember, diantaranya terdapat 96 orang adalah mahasiswa. Banyaknya mahasiswa yang terserang penyakit karena kawasan kampus di Jember merupakan daerah endemis virus hepatitis. Di wilayah kampus terdapat banyak pedagang makanan-minuman yang relatif tidak menjaga kebersihan. Hal ini diduga bahwa mahasiswa mengkonsumsi makanan dan minuman yang terkontaminasi virus. Peralatan yang digunakan untuk menyajikan makanan dan minuman juga diduga terkontaminasi virus (Yumarlis, 2012).

Penelitian ini sangat penting untuk dilaksanakan guna untuk dapat menganalisi perbedaan pengetahuan dan sikap antara mahasiswa kesehatan dan mahasiwa non kesehatan tentang hepatitis A di Politeknik Negeri Jember. Pengetahuan merupakan domain yang sangat penting dalam merubah tindakan seseorang (over behavior), pengetahuan akan membentuk sikap. Diharapkan dengan penelitian ini dapat diketahuinya pengetahuan dan sikap mahasiswa tentang penyakit hepatitis A, sehingga akan berguna untuk dapat melakukan perencanaan tindakan preventif di lingkup politeknik negeri jember, mengingat poletiknik negeri jember merupakan salah satu perguruan tinggi negeri yang besar di Kabupaten Jember.

\section{METODOLOGI}

Penelitian yang dilakukan ini merupakan jenis penelitian survei analitik dengan pendekatan cross sectional. Populasinya merupakan seluruh mahasiswa aktif Politeknik Negeri Jember tahun ajaran 2012/ 2013 yang berjumlah 3180 orang. Jenis sampel yang diambil adalah Strata sampling / Stratified Sampling, dengan menggunakan 50 sampel yaitu 25 sampel mahasiswa di jurusan kesehatan dan 25 sampel mahasiswa diluar jurusan kesehatan di politeknik negeri jember. Pengambilan data dilakukan di kawasan kampus politeknik Negeri jember, tempat kost dan tempat tinggal mahasiswa atau tempat yang memungkinkan untuk dilakukan wawancara. Penelitian ini dilaksanakan pada bulan September 2012 - desember 2012. Pengambilan data dengan menggunakan teknik observasi dan wawancara. Penggalian informasi dengan mengumpulkan data pengetahuan yang behubungan dengan pengetahuan defnisi hepatitis, Jenis hepatits, defnisi hepatis $\mathrm{A}$, penyebab hepatis $\mathrm{A}$, gejala hepatis A, cara penularan hepatis A, cara pencegahan hepatis A. serta data sikap yang berhubungan dengan upaya pencegahan terhadap hepatitis A. Untuk observasi dengan melihat cara melakukan pencegahan dengan menerapkann PHBS (Perilaku Hidup Bersih dan Sehat) yaitu dengan cara cuci tangan dengan baik dan benar. Data dalam penelitian ini akan dianalisis dengan menggunakan uji t-test independen dan Kolmogorov Smirnov.

\section{Hasil Penelitian}

Apabaila pengetahuan mahasiswa tentang hepatitis A secara umum digambarkan adalah sebagai berikut, Mahasiswa yang memiliki pengetahuan sangat baik hingga cukup baik bila di jumlahkan mencapai $50 \%$, sedangkan responden yang memiliki pengetahuan kurang baik hingga tidak baik mencapai $50 \%$ juga. Dapat dilihat lebih rinci akan distribusi pada masing-masing tingkat pengetahuan pada table dibawah ini.

Tabel 1. Pengetahuan Mahasiswa tentang Hepatitis A

\begin{tabular}{rlcc}
\hline No & Pengetahuan Mahasiswa & Frekeunsi & Persentase \\
\hline 1 & Sangat baik & 10 & $20 \%$ \\
2 & Baik & 5 & $10 \%$ \\
3 & Cukup baik & 10 & $20 \%$ \\
4 & Kurang baik & 14 & $28 \%$ \\
5 & Tidak Baik & 11 & $22 \%$ \\
& Jumlah & 50 & 100 \\
\hline
\end{tabular}


Pengetahuan adalah kesan didalam pikiran manusia sebagai hasil penggunaan panca inderanya, yang berbeda sekali dengan kepercayaan (belief), Green (2000), menyebutkan bahawa penigkatan pengetahuan tidak selalu meyebabkan perubahan perilaku. Pengetahuan merupakan faktor penting tidaknya dalam perubahan perilaku kesehatan. Pengetahuan atau kognitif merupakan domaian yang sangat penting untuk terbentuknya tindakan seseorang, karena perilaku yang didasari oleh pengetahuan akan lebih langgeng dari pada tidak didasari pengetahuan (Thoha, M. 2000). Pengetahuan akan hepatitis A tentunya akan mendukung dalam perubahan perilaku kesehatan, yaitu perilaku yang berhubungan dengan upaya preventif, kuratif dan rehabilitatif terhadap hepatitis A. Bila dilihat secara umum pengetahuan mahasiswa akan hepatits A masih separuh responden kurang memiliki pengetahuan yang baik akan hepatitis A. Dari hal tersebut untuk lebih menguatkan perilaku yang mendukung dalam peningkatan kesehatan dibutuhkan sarana untuk menyebarkan informasi tentang hepatitis A yang meliputi upaya preventif, kuratif dan rehabilitatif.
Pengetahuan diperoleh melalui kenyataan (fakta) dengan melihat dan mendengar sendiri, serta melalui alat-alat komunikasi seperti membaca surat kabar, mendengarkan radio, melihat film atau TV dan lain-lain. Pengetahuan atau kognitif merupakan domain yang sangat penting dalam membentuk tindakan seseorang (Notoatmodjo, 2003). Pengetahuan tentang kesehatan sendiri dapat diperoleh dari jalur formal atau pun tidak formal. Untuk jalur formal dapat diperoleh dengan menepuh pendidikan di bidang kesehatan, seperti responden dalam penelitian ini separuh responden menempuh pendidikan dibidang kesahatan yaitu bidang gizi klinik dan rekam medik. Sedangkan untuk separuh responden lainnya dalam memperoleh pengetahuan tentang kesehatannya dapat memperoleh dari berbagai media baik cetak atau elektronik.

Sikap mahasiswa tentang hepatitis A secara umum digambarkan adalah sebagian besar sebanyak 54\% mahasiswa memiliki sikap yang sangat baik dalam upaya pencegahan hepatitis A. Untuk hasil lebih rinci dapat dilahat pada table berikutini

Tabel 2. Sikap Mahasiswa terhadap Hepatitis A

\begin{tabular}{|c|c|c|c|}
\hline No & Sikap Mahasiswa & Frekeunsi & Persentase \\
\hline 1 & Sangat baik & 27 & $54 \%$ \\
\hline 2 & Baik & 10 & $20 \%$ \\
\hline 3 & Cukup baik & 8 & $16 \%$ \\
\hline 4 & Kurang baik & 3 & $6 \%$ \\
\hline 5 & Tidak Baik & 2 & $4 \%$ \\
\hline & Jumlah & 50 & $100 \%$ \\
\hline
\end{tabular}

Menurut Notoatmodjo (2003)
pengetahuan merupakan domain yang sangat penting dalam merubah tindakan seseorang (over behavior), pengetahuan akan membentuk sikap. Sikap adalah penilaian seseorang terhadap stimulus atau obyek. Sikap belum merupakan suatu tindakan. Sikap adalah penilaian seseorang terhadap stimulus atau objek. Setelah seseorang mengetahui stimulus atau objek proses selanjutnya akan menilai atau bersikap terhadap stimulus atau objek kesehatan tersebut.

Newcomb dalam Notoatmodjo (2003), menyatakan bahwa sikap itu merupakan kesiapan atau kesediaan untuk bertindak dan bukan merupakan pelaksanaan motif tertentu. Sikap merupakan suatu tindakan atau aktivitas, akan tetapi merupakan predisposisi tindakan suatu perilaku.

Dari hasil penelitian diatas sebagaian besar mahasiswa memiliki sikap yang baik dalam upaya yang berhubungan dengan upaya pencegahan penyakit hepatitis $\mathrm{A}$, hal ini perlu dipertahankan. Tetapi sebagian kecil lainnya responden masih ada yang memiliki sikap yang kurang baik, hal ini tidak mendukung pada perilaku kesehatan. Perlu dilakukan peningkatan pengetahuan yang lebih baik, dengan pengetahuan yang baik maka akan membentuk sipa yang baik pula.

Sikap yang baik akan mengakibatkan perilaku pencegahan tentang hepatitis A dengan baik pula, seperti hasil observasi pada responden diketahui cara pencegahan yang yang paling mudah adalah dengan perilaku hidup bersih dan sehat (PHBS) yaitu dengan cara mencuci tangan dengan baik dan benar seperti mencuci tangan dengan air yang mengalir, menggunakan sabun atau antiseptic dan semua bagian tangan terkana sabun atau antiseptic pada saat mencuci. Sebagian besar responden yaitu $64 \%$ telah bisa melakukan 
cuci tangan dengan baik dan benar, 22\% responden lainnya cukup baik dalam mencuci tangan, dan $14 \%$ lainnya tidak bisa mencuci tangan dengan baik dan benar.

Dalam Notoatmodjo (2003), menjelaskan bahwa sikap itu mempunyai 3 komponen pokok yaitu, kepercayaan (keyakinan), ide dan konsep terhadap suatu objek, kehidupan emosional atau evaluasi terhadap suatu objek dan kecenderungan untuk bertindak (tend to behave). Ketiga komponen ini secara bersama-sama membentuk sikap yang utuh (total attitude).

Dalam penentuan sikap yang utuh ini, pengetahuan, pikiran, keyakinan dan emosi memegang peranan penting. Dari data diatas pengetahuan akan hepatitis A yang baik akan mengahsilkan sikap yang baik yaitu sikap mendukung pada upaya pencegahan sehingga akan baik pula dalam berperilaku untuk melakukan pencegahan agar tidak tertular hepatitis A, seperti dengan cara mencuci tangan dengan baik dan benar.

Untuk mengetahui rata-rata perbedaan pengetahuan tentang hepatitis A pada mahasiswa kesehatan dan non kesehatan, maka dilakukan uji statitistik parametrik dengan menggunakan uji independent sampel t test. Dari hasil uji tersebut diketahui $p$ value sebesar 0,124 dimana lebih besar dari alpha yaitu 0,05 , hal ini berarti $\mathrm{H} 0$ diterima. Kesimpulannya adalah tidak terdapat perbedaan pengetahuan tentang hepatitis A antara mahasiswa kesehatan dan non kesehatan. Hal ini disebabakan pada jurusan kesahatan yaitu program studi gizi klinik dan Rekam medik, baik dari semester I hingga smester VII responden hanya mendapatkan kuliah pengantar patologi secara umum dan tidak membahas secara mendalam tentang hepatitis A. hal inilah yang menyebabkan pengetahuan mahasiswa kesehatan dan non kesehatan tidak ada bedanya.

Menurut Sumarman (2010) faktor faktor yang mempengaruhi pengetahuan seseorang antara lain : intelegensia, pendidikan, informasi dan faktor lingkungan selain itu juga pengetahuan dapat di peroleh dari pengalamanpengalaman, seperti kata pepatah pengalaman merupakan guru yang terbaik yang mengandung maksud bahwa pengalaman merupakan suatu cara untuk memperoleh kebenaran pengetahuan (Notoatmodjo, 2003).

Sedangkan untuk mengetahui rata-rata perbedaan sikap tentang hepatitis A pada mahasiswa kesehatan dan non kesehatan, menggunakan uji statitistikn non parametrik dengan menggunakan uji TwoSample Kolmogorov-Smirnov Test karena data tidak normal. Dari hasil uji tersebut diketahui $p$ value sebesar 0,699 dimana lebih besar dari alpha yaitu 0,05, hal ini berarti H0 diterima. Kesimpulannya adalah tidak terdapat perbedaan sikap tentang upaya pencegahan hepatitis A antara mahasiswa kesehatan dan non kesehatan.

Menurut Allaport dalam O'Sears (2002), sikap adalah keadaan mental dan saraf dari kesiapan yang diatur melalui pengalaman yang memberikan pengaruh dinamik atau terarah terhadap proses respon individu pada semua objek dan situasi yang berkaitan dengannya. Karena definisi ini sangat dipengaruhi oleh tradisi belajar, juga ditekankan bagaimana pengalaman masa lalu membentuk sikap. Pengalaman akan hepatitis A bisa diperoleh dengan merasakan sendiri atau mungkin belajar dari lingkungan sebelumnya dimana di daerah kampus merupakan daerah endemik hepatitis A dimana banyak mahasiswa yang tertular hepatitis A hal ini dilahat dari laporan Dinas Kesehatn Jember pada maret 2012, sedikitnya terdapat penderita hepatitis A sebanyak 120 orang yang harus dirawat di sejumlah rumah sakit dijember, diantaranya terdapat 96 orang adalah mahasiswa. hal ini akan membentuk sikap yang lebih hati-hati pada mahasiswa sehingga pembentukan sikap dalam upaya pencegahan hepatitis A dapat dengan baik dipertahankan.

\section{KESIMPULAN}

Meningkatkan Pengetahuan mahasiswa tentang hepatitis A sangatlah mendukung dalam upaya pencegahan mengingat $50 \%$ mahasiswa yang memiliki pengetahuan kurang baik hingga tidak baik. Masih ada sebagia kecil mahasiswa yang memiliki sikap kurang baik hingga tidak baik terhadap upaya pencegahan terhadap penyakit hepatitis A. Dari hasil analisis diketahui tidak terdapat perbedaan pengetahuan dan sikap tentang hepatitis A antara mahasiswa kesehatan dan non kesehatan.

\section{SARAN} berikut :

Dari hasil penelitian ini disarankan sebagai

1. Perlunya dilakukan peningkatan pengetahuan akan hepatitis A dengan memanfaatkan media yang dapat dimanfaatkan, yang ada di area kampus, seperti baliho, papan pengumuman, majalah dinding,ataupun website POLIJE. Ini merupakan upaya preventif agar kejadian hepatitis A dapat menurun di area kampus POLIJE.

2. Perlunya sarana penunjang PHBS (Perilaku Hidup Bersih dan Sehat) seperti toilet dan tempat cuci tangan yang sebading dengan 
3. jumlah mahasiswa POLIJE yang semakin banyak, hal ini untuk mendukung upaya preventif.

4. Bagi penelitian selanjutnya untuk mencegah hepatitis A kembali merebak perlunya diadakan penelitian pada tempat penjual makananan yang berada di area kampus, mengingat $84 \%$ mahasiswa POLIJE merupakan anak kost.

\section{DAFTAR PUSTAKA}

1. Afiati, AI. 2011. Infeksi Hepatitis A dan Pencegahannya.

http://labparahita.com/parahita/2011/01/ penyakit-hepatitis-a-pencegahannya/. (21 September 2012)

2. Dhafinah. 2012. Mengenal Hepatitis A. http://dhafinatallah. wordpress.com/ mengenal-hepatitis-a/ (21 September 2012)

3. Green, LW. Kreuter, MW. Health Promotion Planning An Educational and Environmental Approach. Second Edition. Mayfield Publishing Company. London ; 2000
4. Notoatmodjo, S. 2003. Pendidikan dan Perilaku Kesehatan. Cetakan I. Jakarta: Rineka Cipta

5. Notoatmodjo, S. 2005. Metode Penelitian Kesehatan. Jakarta: Rineka Cipta

6. Nursalam. 2003. Konsep Penerapan Metodologi Penelitian Ilmu Keperawatan. Jakarta : Salemba Medika.

7. O'Sears. 2002. Psikologi Sosial. Jilid I. Edisi V. Jakarta: Erlangga

8. Sedarmayanti dan Hidayat. 2002. Metode Penelitian. Bandung: CV. Mandar Maju

9. Sugiyono. 2006. Metode Penelitian. ALFABETA : Bandung

10. Sugiyono. 2011. Metode Penelitian Kuantitatif, Kualitatif dan R\&D. ALFABETA : Bandung

11. Sulaiman, Ali. Julitasari. 1995. Virus Hepatits A Sampi E di Indonesia. Yayasan Penerbitan Ikatan Dokter Indonesia.

12. Sumarman. 2010. Penderita Hipertensi Primer : Pengetahuan Tentang Diet Rendah Garam, Kepatuhan dan Kendalanya. Program Pascasarjana Universitas Sebelas Maret Surakarta.

13. Thoha, M. Perilaku Organisasi Konsep dasar dan Aplikasinya. PT Raja Grafindo Persada. Jakarta. 2000 